\title{
Spatial Planning in Localities with Special Historic Values on Examples of Poland and Slovakia***
}

\begin{abstract}
One of the objectives of spatial planning policy is the protection of cultural heritage and historical monuments. Since this objective is necessary to be included it in planning documents, it means that spatial planning procedures shall comprise actions associated with the conscious shaping of cultural landscapes and protection of historical objects. Nevertheless, it is believed that these possibilities are not sufficiently used in Polish planning documents.

This paper aims to compare the spatial planning systems found in Poland and Slovakia, with a particular emphasis on the conditions that must be taken into account when creating planning documents in historic localities.

An analysis of sample documentation prepared for localities with special historical values (Lanckorona in Poland and Levoča in Slovakia) allowed the authors to conclude that local development plans in Slovakia contain fewer details related to the protection of cultural values and monuments than those adopted in Poland. This is a consequence of the fact that the only institution to evaluate this issue in Slovakia is the provincial conservator.
\end{abstract}

Keywords: Lanckorona, Levoča, local development plan, protection of cultural values, protection of monuments, UNESCO

* AGH University of Science and Technology, Faculty of Mining Surveying and Environmental Engineering, Department of Geomatics, Krakow, Poland

** Technical University of Košice, Faculty of Mining, Process Control and Geotechnologies, Institute of Geodesy, Cartography and GIS, Košice, Slovakia

*** This study has received the financial support from the statutory research no. 11.11.150.006 


\section{Introduction}

Spatial planning is a key aspect in the context of the proper development of the world around us, and protection of monuments is one of the basic objectives for creating planning documents [15]. Clear regulations coordinating and ordering the existing spatial development introduced in local development plans are aimed at avoiding the chaos that lowers the value of historic cities [4]. It can, therefore, be concluded that the local plan is an act of conscious shaping of the cultural landscape [23] and is one of the forms of protection of historical monuments, which are an important element of cultural heritage [16]. However, the analysis of the national conservation practice reveals that the planning documents are not sufficiently used for this purpose [23].

The countries of Central and Eastern Europe willingly compare themselves with the countries of the so-called Old European Union; this is also true with reference to spatial planning, as confirmed by [5, 6, 14, 21, 22].

Although real estate procedures are carried out in accordance with state provisions, there are some features common to all post-socialist countries [9]. The situation may also be similar in the case of spatial planning, as demonstrated in [14] and [18]. This is why this research paper aims to compare the spatial planning systems governing Poland and Slovakia, with a particular emphasis on the conditions that must be taken into account when creating planning documents in historic localities.

\section{Methodology and Materials}

The research involved the analysis of selected elements of the spatial planning systems of Poland and Slovakia using the comparative method. The focus was placed on the legal context as well as provisions related to the particular conditions of spatial planning contained in specific spatial planning documents at the local level in localities with historic values.

The spatial planning systems in both countries operate based on relevant normative acts. In Poland, it is the Act on Spatial Planning and Land Development of March 27, 2003 [26]. In Slovakia, on the other hand, it is the Act on Spatial Planning and Building Regulations of April 27, 1976 [29].

In both cases, statutory provisions allow for the preparation of local development plans defining land use and the manners of management of the areas delimited from the planning space. Both the Polish and Slovakian plans must contain principles of protecting cultural values and monuments. Its implementation in practice was verified by analyzing the records of local plans in localities with special historical values. The local spatial development plan for the commune of Lanckorona was selected from the Polish planning documents [24], and that for the town of Levoča was chosen from the Slovakian documents [27]. 


\section{Comparison of Selected Elements of Spatial Planning in Poland and Slovakia}

Spatial planning is a group of system actions that refer to the future status of space. These actions are undertaken by relevant public administration bodies based on the existing status of spatial development. It is a process that is implemented at various levels of detail, with proper planning studies prepared at each level [3]. This is the reason why the authors started with a general comparison of the entire spatial planning systems in Poland and Slovakia. Then, it was verified whether the procedures for the preparation of local development plans in Poland and Slovakia were similar and whether the content presented in them corresponded with each other.

\subsection{Spatial Planning System}

Spatial planning procedures in Poland are implemented based on the Act on Spatial Planning and Land Development of 2003 [26]. According to its provisions, spatial planning is a process that is carried out at three levels: national, provincial (regional), and communal (local). This three-stage spatial planning system functions despite the four-level administrative division of the country. A county does not really participate in the planning activities [1].

The basic planning document in Poland is the Concept of Spatial Development of the Country [13]. It defines the conditions, objectives, and directions of sustainable development of the country as well as the actions that are necessary to achieve it. It is prepared by the minister responsible for construction, planning, spatial development, and housing. All of the planning documents prepared by provinces and communes must be compliant with its provisions.

One level lower, the self-government bodies of a province draw up a spatial development plan for this province.

However, the most-important planning activities are those that are carried out in communes [3]. They refer to the immediate surroundings of the inhabitants and are thus performed at the highest level of detail.

In commune spatial planning, the local development plan and study of the conditions and directions of spatial development of the commune are the most important. At this level, planning permissions are also issued based on which administrative decisions are issued in the absence of a local development plan; these include building permits or decisions on real estate subdivision.

Table 1 presents the characteristics of the planning documents prepared in Poland.

In Slovakia, spatial planning is regulated by the Act on Spatial Planning and Building Regulations of 1976 as amended [29]. As in Poland, spatial planning procedures are implemented at three levels: national, regional, and communal (local). 


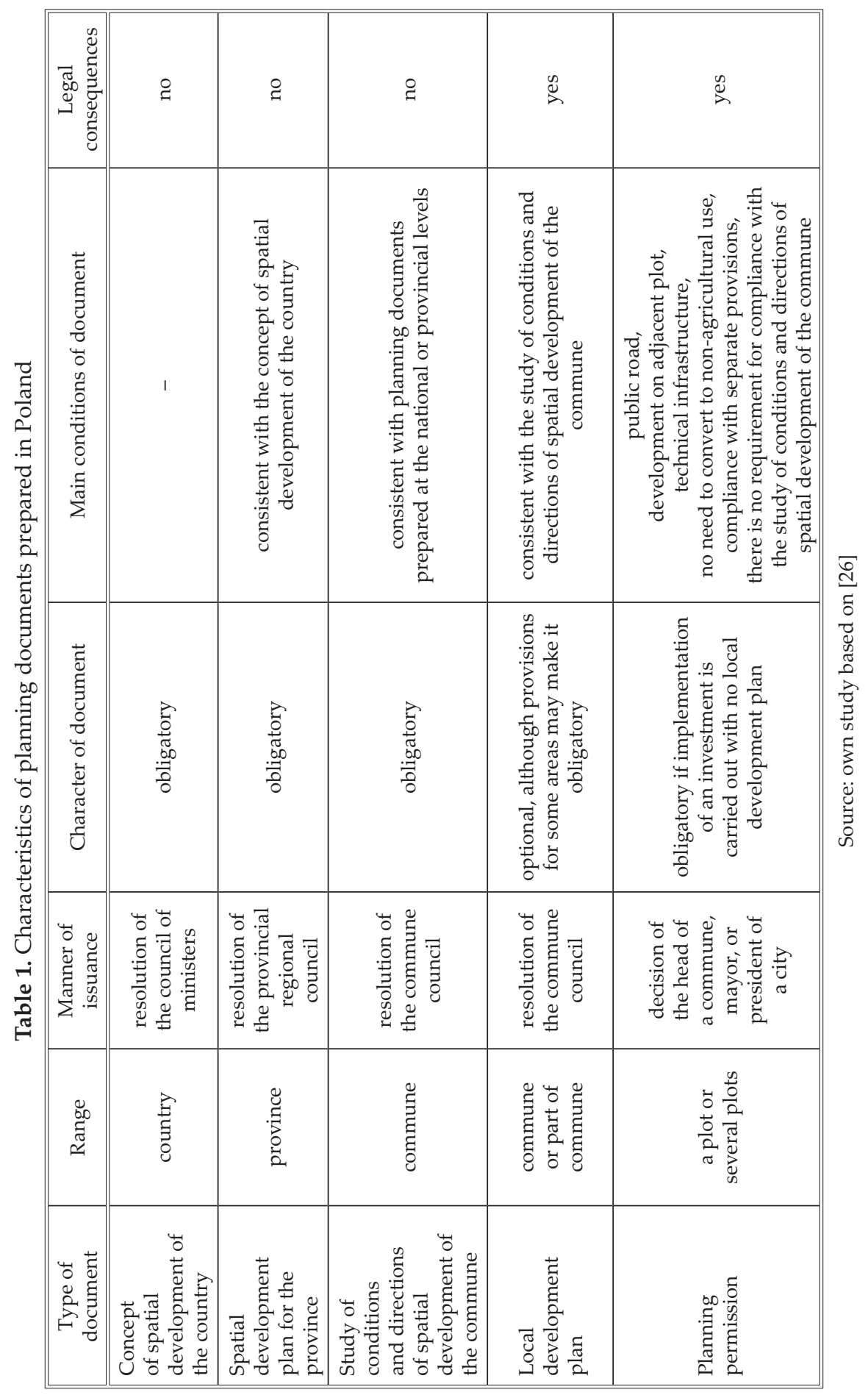


The Concept of the Spatial Development of Slovakia is developed for the entire territory of the Slovak Republic. It defines the social, economic, natural, and cultural conditions for the purpose of territorial development of the country as well as protection of the environment and landscape.

The concept is binding when regional development plans are being prepared. These plans are developed for a part of the country consisting of many communes where specific development objectives or activities with significant influence on the spatial and functional layout are to be implemented. The boundaries of the area covered by the regional development plan are determined by the body that developed the plan.

Local spatial development plans are prepared at the local level. They are developed within the boundaries of one, two, or more communes. Only communes inhabited by more than 2000 people are obligated to have a plan, as well as smaller communes if they must solve a territorial development problem (e.g., implementing extensive construction or reconstruction plans or locating public purpose investments) or if they are obligated by the regional development plan (especially in order to meet international obligations or to locate investments for technical and road infrastructure of a national importance).

The local development plan specifies which parts of the commune zonal development plans that should be additionally prepared.

Table 2 presents the characteristics of the planning documents developed in Slovakia.

Table 2. Characteristics of planning documents developed in Slovakia

\begin{tabular}{|l|c|c|c|c|c||}
\hline \multicolumn{1}{|c|}{$\begin{array}{c}\text { Type of } \\
\text { document }\end{array}$} & Range & $\begin{array}{c}\text { Manner of } \\
\text { issuance }\end{array}$ & $\begin{array}{c}\text { Character } \\
\text { of document }\end{array}$ & $\begin{array}{c}\text { Main conditions } \\
\text { of document }\end{array}$ & $\begin{array}{c}\text { Legal } \\
\text { consequences }\end{array}$ \\
\hline \hline $\begin{array}{l}\text { Concept } \\
\text { of spatial } \\
\text { development } \\
\text { of Slovakia }\end{array}$ & country & $\begin{array}{c}\text { approved } \\
\text { by the } \\
\text { government }\end{array}$ & obligatory & no \\
\hline $\begin{array}{l}\text { Regional } \\
\text { spatial } \\
\text { development } \\
\text { plan }\end{array}$ & $\begin{array}{c}\text { several } \\
\text { or more } \\
\text { communes }\end{array}$ & $\begin{array}{c}\text { approved } \\
\text { by the } \\
\text { regional self- } \\
\text { government }\end{array}$ & optional & $\begin{array}{c}\text { consistent with the } \\
\text { concept of spatial } \\
\text { development of } \\
\text { Slovakia }\end{array}$ & no \\
\hline $\begin{array}{l}\text { Local } \\
\text { development } \\
\text { plan }\end{array}$ & $\begin{array}{c}\text { a commune } \\
\text { or several } \\
\text { communes }\end{array}$ & $\begin{array}{c}\text { approved by } \\
\text { the commune } \\
\text { communes } \\
\text { inhabited by } \\
\text { more than 2,000 } \\
\text { inhabitants and } \\
\text { in specific cases } \\
\text { also in smaller } \\
\text { communes }\end{array}$ & $\begin{array}{c}\text { consistent with the } \\
\text { regional spatial }\end{array}$ & yes \\
\hline $\begin{array}{l}\text { Zonal } \\
\text { development } \\
\text { plan }\end{array}$ & $\begin{array}{c}\text { part of } \\
\text { a communentan }\end{array}$ & $\begin{array}{c}\text { approved by } \\
\text { the commune }\end{array}$ & optional & $\begin{array}{c}\text { consistent with the } \\
\text { local development } \\
\text { plan }\end{array}$ & yes \\
\hline \hline
\end{tabular}

Source: own study based on [29] 
It is easily noticeable that there are many common features in the spatial planning systems of Poland and Slovakia. Differences occur only at the regional and local levels. Unlike in Poland, the territorial range of the documents created at these levels in Slovakia is not rigidly determined by the administrative division of the country. Moreover, Slovak legislation does not provide for documents that could be comparable to Polish planning permissions. In the absence of a local development plan or zonal development plan, administrative decisions are issued based on the existing strategic documents and background maps on which such plans may be developed.

\subsection{Preparation Procedure for Local Development Plan}

Since the planning activities that are carried out in communes should be considered most important, another comparable element of the spatial planning of Poland and Slovakia is the preparation procedure for a local development plan. This is implemented as a whole by the commune self-government bodies (Tab. 3).

Table 3. Local government bodies in communes

\begin{tabular}{|c|c|c|}
\hline Type & Poland & Slovakia \\
\hline decision-making & $\begin{array}{l}\text { commune council (in rural communes), } \\
\text { municipal council (in rural-urban } \\
\text { communes), } \\
\text { town or city council (in municipalities) }\end{array}$ & $\begin{array}{l}\text { commune council (in rural communes), } \\
\text { town or city council (in towns/cities) }\end{array}$ \\
\hline executive & $\begin{array}{c}\text { head of a commune } \\
\text { (in rural communes), } \\
\text { mayor (in rural-urban communes } \\
\text { and municipalities with fewer than } \\
100,000 \text { inhabitants), or president (in } \\
\text { municipalities with more than 100,000 } \\
\text { inhabitants }\end{array}$ & $\begin{array}{l}\text { district governor (in rural communes), } \\
\text { or mayor (in towns/cities) }\end{array}$ \\
\hline
\end{tabular}

Source: own study based on $[25,30]$

In Poland, this procedure begins with the commune council's resolution to proceed with the preparation of the local development plan [26]. This resolution may be adopted by the commune council (municipal council or city/town council - c.f. Table 3) on its own initiative or at the request of the commune head (mayor or president of the city - c.f. Table 3). Before the resolution is adopted, the body responsible for developing the plan should carry out analyses regarding grounds for proceeding with the plan and compliance of the anticipated solutions with the provisions of the study of the conditions and directions of the spatial development of the commune. Moreover, the body also prepares any geodetic materials necessary for developing the plan and determines the required scope of the planning work. 
Having adopted an appropriate resolution, the head of the commune shall perform the following tasks:

1. Announce information in the local press about the adoption of a resolution on proceeding with the plan by way of an announcement or in the manner customarily adopted in a given locality, specifying the form, place, and deadline for submitting proposals to the plan (which cannot be shorter than 21 days from the day of this announcement).

2. Notify in writing the institutions and authorities competent to approve and express opinion on the plan that a resolution on proceeding with the preparation of the plan has been adopted.

3. Develop a draft plan, taking into account the proposals submitted after announcing the adoption of a resolution on proceeding with the preparation of a plan, and prepare an environmental impact assessment for the plan.

4. Prepare a forecast of the financial impact of the adoption of a local plan.

5. Collect opinions issued on the draft plan by the following:

a) commune or other competent urban and architectural commission,

b) heads of communes, mayors, or presidents of towns or cities bordering the area covered by the plan regarding the distribution of public purpose investments of local importance,

c) regional director for environmental protection,

d) competent geological administration authorities regarding documented deposits of minerals and groundwater,

e) competent authority of the state fire service and provincial inspector for environmental protection regarding the location of new plants with an increased or high risk of major accidents, changes in the existing plants with increased or high risk of major accidents, new investments as well as distribution of public space areas and residential areas in the vicinity of plants with an increased or high risk of major accidents, if these investments or areas increase the risk or consequences of major accidents,

f) competent provincial public health inspector,

g) district governor, as the competent authority for environmental protection regarding areas threatened by landslides,

h) power transmission system operator with respect to the manner of managing the land located at a distance of a maximum of 40 meters from the axis of the existing high voltage power line, if the upper voltage of this power line is at least $220 \mathrm{kV}$.

6. Approve the content of the draft plan with:

a) provincial governor, province management, county management, regarding appropriate government and self-government tasks,

b) authorities competent to approve the content of a draft plan based on separate regulations, 
c) competent road manager, if the manner of development of the land adjacent to the right-of-way (or change of this manner) may have an impact on traffic or on the road itself,

d) competent military, border control, and state security authorities,

e) director of relevant maritime office regarding the development of a service strip, a protective strip, sea ports, and marinas,

f) competent mining supervision authority regarding the development of mining areas,

g) minister competent for health matters regarding the development of spa areas,

h) competent provincial conservator of monuments regarding the shaping of development and land management,

i) province management regarding the results of a landscape audit.

7. Be granted consent to change the use of agricultural and forest land to non-agricultural and non-forest purposes.

8. Introduce changes resulting from the expressed opinions and carried-out approvals.

9. Announce information in the local press about making the draft plan available for public review by way of an announcement (or in the manner customarily adopted in a given locality) at least 7 days prior to the date of its presentation and make it available together with the environmental impact assessment for a period of at least 21 days. During this time, the head of the commune shall organize a public discussion on the solutions adopted in the draft plan. The announcement shall define a deadline (not shorter than 14 days after the lapse of the period of the draft plan being available for public review) before which natural and legal persons as well as organizational units without a legal personality may submit comments on the draft plan.

10. Analyze the submitted comments within a maximum of 21 days from the deadline of their submission.

11. Introduce changes to the draft local plan resulting from the analysis of those comments and then (to the necessary extent) renew the settlements.

12. Present the draft local plan together with a list of the disregarded comments to the commune council.

The commune council adopts the local plan, having stated that it does not violate the settlements of the study, at the same time deciding on the manner of considering comments on the draft plan and the manner of implementing investments in the technical infrastructure (which belong to the commune's own tasks) as well as the principles of their financing (pursuant to the provisions on public finances). The resolution is the text document of the plan, while the graphical part and the required solutions constitute appendices to the resolution. 
The final version of the resolution along with the appendices and documentation of the planning works are presented to the provincial governor by the head of the commune in order to assess their compliance with legal provisions. The resolution and appendices thereto, approved by the provincial governor, are published in the Official Journal of the Province. The local spatial development plan comes into force on the date set out in the resolution, counted from the date of the publication in the Official Journal. At this point, the plan becomes a local law, applicable to everyone in a given area.

The process of preparing and implementing a local spatial development plan in Slovakia is carried out in the following order [29]:

1. The commune begins to develop the local plan on its own initiative or on the initiative of another public management body, a natural person, or a legal person.

2. The commune designates a person who shall be held responsible for creating a draft plan. Such a person can be selected from the register maintained by the ministry. A person who comes from the region where the commune is located is the best choice. Knowledge of the region, the relationships between the planning activities in the region, and mutual spatial relationships between individual municipalities are great advantages.

3 . The commune and the person responsible for developing the plan implement preparatory works, which means that they do the following:

a) publicly announce the willingness to develop a plan,

b) collect the documentation necessary to develop the plan and state its suitability,

c) determine the main objective and subject of the plan.

4. The commune and the person responsible for developing the plan prepare tender conditions in order to select the contractor of the plan. The best offer is selected by an independent tender commission.

5. The contractor carries out spatial analyses essential for the preparation of the plan and defines the directions of the spatial policy proposed for the commune as well as the problems to be solved in the plan.

6. The commune analyzes the contractor's proposals. However, they can be accepted only after public consultations and acceptance by the provincial construction office.

7. The contractor creates a multi-variant draft plan.

8. The commune consults the draft plan with the inhabitants, province, provincial construction office, interested bodies, owners of technical infrastructure, and neighboring communes.

9. The person responsible for developing the plan assesses the documentation prepared by the contractor and selects the optimal solution for the commune from many variants of the plan that will be presented in the final draft plan.

10. The contractor prepares the final draft plan. 
11. The commune consults the final draft plan with the neighboring communes, competent province, as well as state authorities and legal persons who will be affected by the draft plan.

12. The construction supervision authority examines whether the content of the draft plan and the process of its preparation are in accordance with the law and with the spatial development plan of the region, and whether the draft plan also applies to neighboring regions.

13. The commune adopts the local spatial development plan. The adopted local plan is binding in the preparation of the zonal development plan, issuing construction permits and preparing documentation for the construction projects being implemented.

These procedures are similar to each other; however, two important differences should be highlighted. The Polish law obligates the executive body of the commune to develop the plan (which, in practice, is not performed on its own, anyway). The Slovak regulations immediately speak about the necessity of appointing people who are independent of the commune for this purpose. Moreover, unlike in Poland, the supervisory body verifies the draft plan before its adoption in Slovakia.

\subsection{Scope of Local Development Plan}

In Poland, it is obligatory for the local plan to include the following [26]:

1) land use and lines delimiting areas with different intended purposes or different development principles;

2) principles of protection and shaping of spatial order;

3) principles of environmental, nature, and landscape protection;

4) principles of landscaping;

5) principles of protecting cultural heritage and monuments, including cultural landscapes and contemporary cultural goods;

6) requirements resulting from the needs of shaping public spaces;

7) principles of shaping the development and land development ratios, maximum and minimal building density as a ratio of total development area relative to the surface area of a building plot, minimum percentage of soft landscape area relative to the surface area of a building plot, maximum height of the development, minimum number of parking places (including places designated for parking vehicles provided with parking cards and the manner of their implementation), as well as building frontage lines and overall dimensions of the building structures;

8) boundaries and manners of developing the areas or structures subject to protection based on separate regulations, mining areas as well as flood hazard areas, areas of landslides, priority landscapes defined in the landscape audit, and in provincial spatial development plans; 
9) detailed principles and conditions of the reparcelling and subdividing the real estate included in the local plan;

10) special conditions for land management and restrictions on their use, including ban on development;

11) principles of modernization, development, and construction of communication systems and technical infrastructure;

12) method and date of temporary management, arrangement, and use of land;

13) percentage rates, based on which the planning fees are determined.

Additionally, the local plan shall specify the following (depending on the needs):

1) boundaries of the areas requiring the reparcelling and subdividing real estate;

2) boundaries of the areas of rehabilitation of the existing development and technical infrastructure;

3) boundaries of the areas requiring transformation or reclamation;

4) boundaries of the areas intended for the construction of facilities generating energy from renewable energy sources with a capacity exceeding $100 \mathrm{~kW}$ and the boundaries of their protection zones related to restrictions on the development, management, and use of these areas, and associated with the occurrence of any significant environmental impact caused by these facilities;

5) boundaries of the areas intended for the construction of commercial facilities with a sales area exceeding $2000 \mathrm{~m}^{2}$;

6) boundaries of the areas intended for the implementation of public purpose investments of local importance;

7) boundaries of the areas intended for public purpose investments of supra-local importance, included in the spatial development plan of the province or in final decisions on the location of the national, provincial, or county road, railway line of national importance, public airport, terminal, or Euro 2012 investment;

8) boundaries of recreational areas as well as areas for the organization of mass events;

9) boundaries of monuments of extermination and their protection zones as well as restrictions on running business activity in these areas, defined in the act on the protection of former Nazi concentration camps;

10) boundaries of the enclosed areas, and boundaries of the protection zones of the enclosed areas;

11) manner of locating construction works relative to roads and other publicly accessible areas and to the boundaries of adjacent real estate, colors of building structures, and roofing;

12) minimal surface area of newly separated building plots. 
In Slovakia, on the other hand, local spatial development plans specify the following in particular [29]:

1) rules and regulations regarding the spatial organization and functional use of the commune territory in relationship to the surrounding area;

2) permitted, limited, and banned functional use of the area,

3) rules and regulations regarding environmental protection, territorial system of ecological stability, and landscape creation, including green areas;

4) rules and regulations regarding the protection and exploitation of natural resources, cultural and historical values, as well as important landscape features;

5) a boundary between the built-up area of the commune or the area intended for development and other areas of the commune;

6) rules and regulations regarding public transport and technical equipment as well as civil equipment;

7) areas of public works, sanitation protection zones, and protected parts of the country.

These provisions are detailed by the zonal development plans, which contain the following:

1) rules and regulations regarding a more-detailed spatial organization and functional use of the land, buildings, and public transport as well as the technical equipment of a given territory;

2) rules and regulations regarding the distribution of buildings on individual plots in urban areas and the construction conditions of individual building plots;

3) plots of land that are located in a built-up area of the commune, buildings on building plots, and their share of the total area;

4) undeveloped land intended for development, including the definition of land that cannot be further classified as a building plot (according to the local spatial development plan);

5) protected areas;

6) rules and regulations regarding the necessary fixtures and fittings of the buildings and their connection to the communication network as well as provision of the media;

7) rules and regulations regarding the integration of buildings with the environment, including historical and monumental buildings;

8) distribution of green areas, important landscape features, and other elements of the territorial ecological stability system on individual plots;

9) real and temporary coordination of new development and the renovation of existing buildings;

10) plots of land for public-purpose investments, closing, and reconstructing a building. 
The provisions required to be contained in Polish local spatial development plans are more-extensive than those that should be included in the Slovak plans. In Slovakia, more-detailed provisions affecting the planning space appear only in zonal development plans.

\section{Specific Conditions of Spatial Planning in Historic Localities}

In order to verify which records may be included in the local spatial development plans prepared for localities with special historic values, the documents created for two historic localities were analyzed: for Lanckorona (Poland, Malopolska province, Wadowice county, seat of the commune of Lanckorona) and Levoča (Slovakia, Prešov region, seat of Levoča county).

\subsection{Local Spatial Development Plan for Lanckorona (Poland)}

Lanckorona is a village located approximately $30 \mathrm{~km}$ south of Krakow (Fig. 1) at an average altitude of 545 meters above mean sea level. It covers an area of $11.8 \mathrm{~km}^{2}$. Its population is a little over 2000 inhabitants. Lanckorona's housing development and agricultural fields are located in the valley of the Skawinka River and on the slopes of the Lanckorona Mountain called Castle Hill (Fig. 2). The village has preserved the original wooden buildings from the second half of the $19^{\text {th }}$ century (Fig. 3). There are ruins of a medieval castle of the Lanckorona district governors located on Castle Hill.

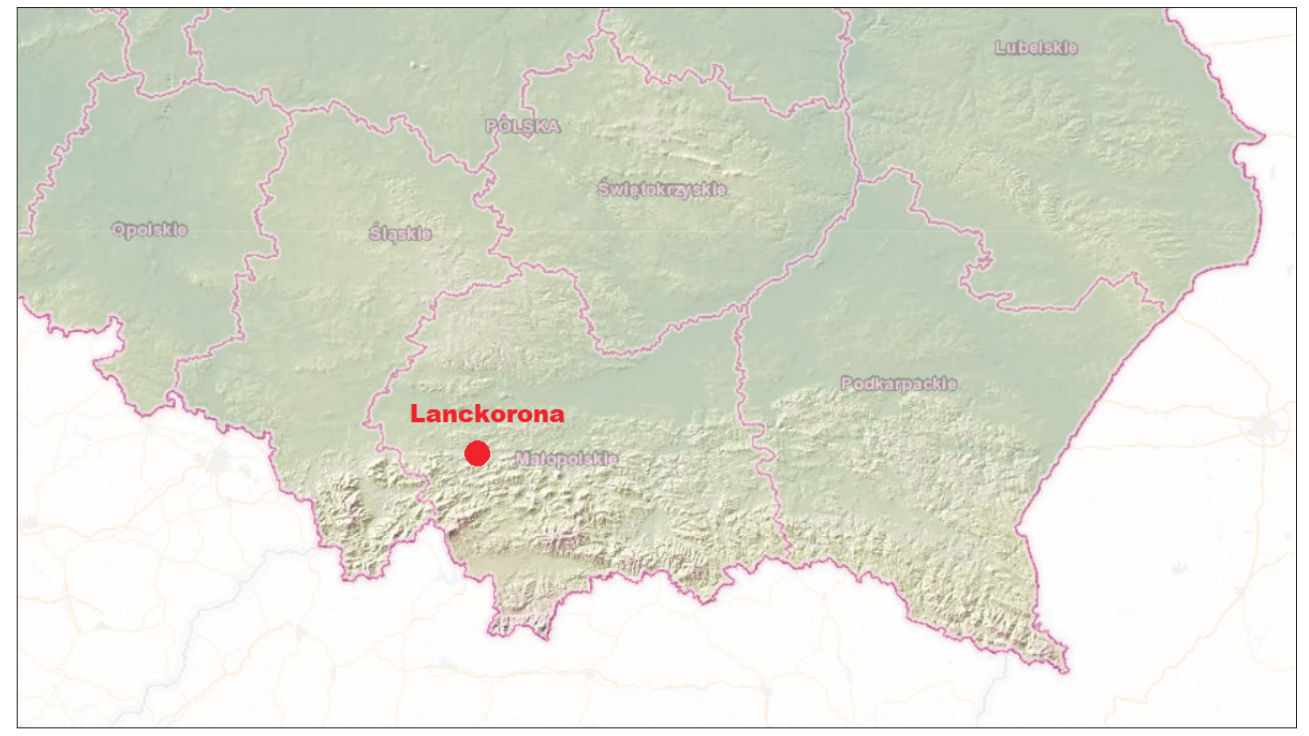

Fig. 1. Location of Lanckorona

Source: own study based on [6] 


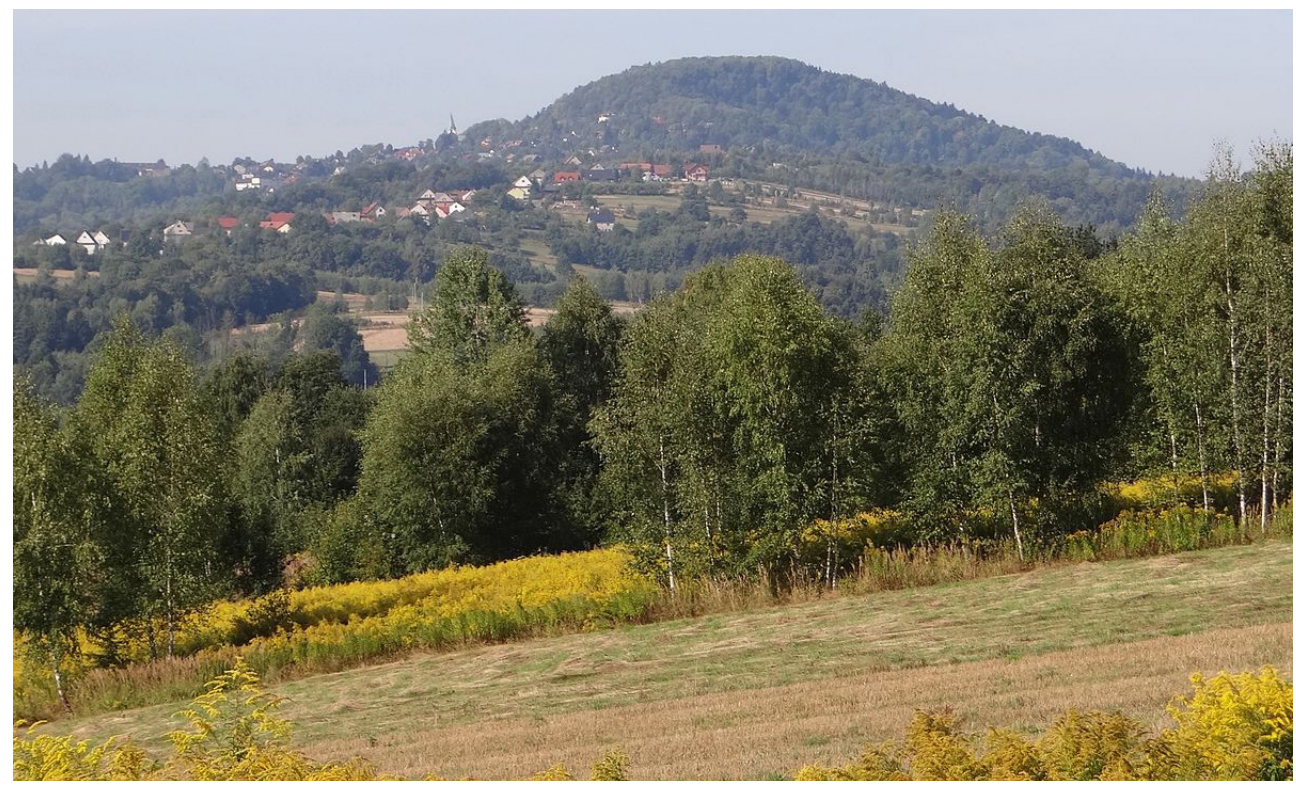

Fig. 2. View of Lanckorona Mountain (phot. Jerzy Opioła)

Source: [28]

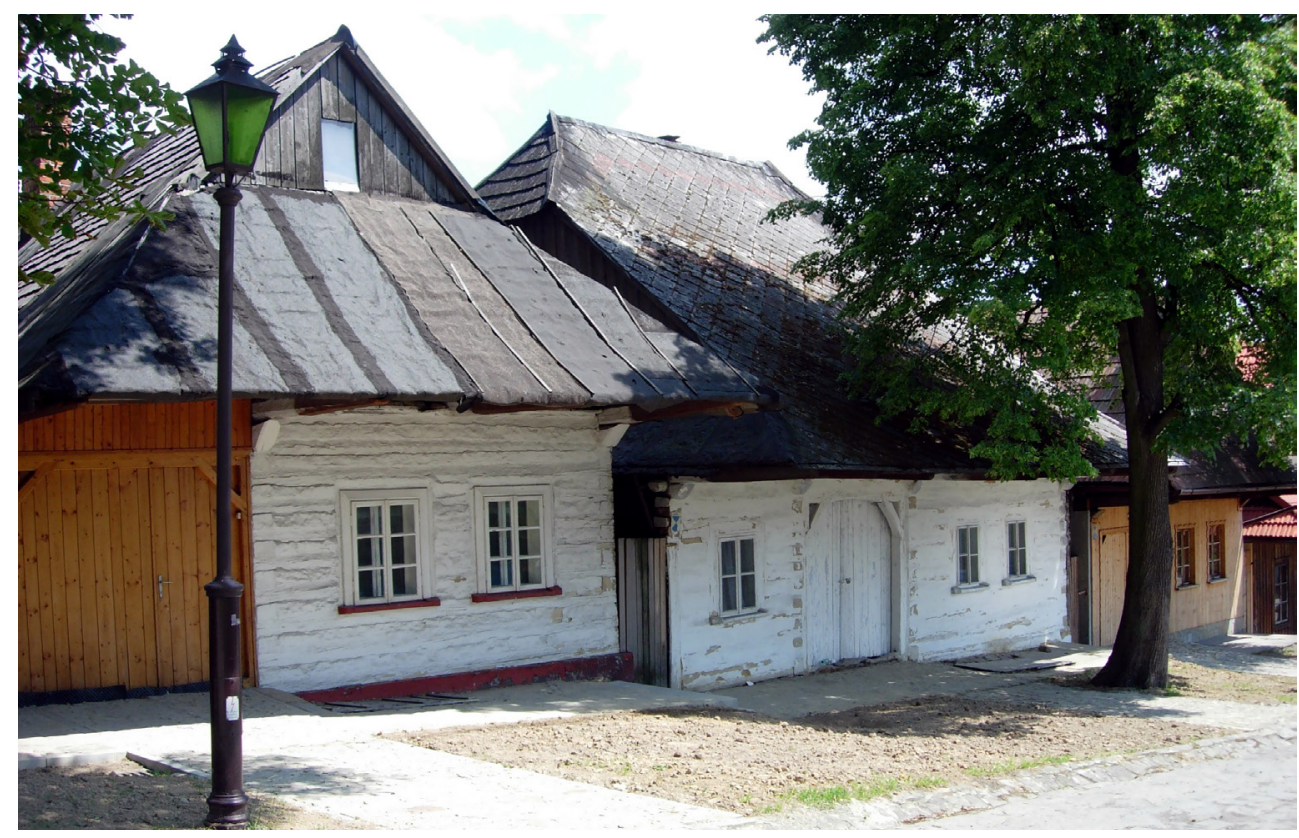

Fig. 3. Historical development of market in Lanckorona (phot. Jakub Hałun)

Source: [11] 
This part of the commune (with an area of approx. $0.5 \mathrm{~km}^{2}$ ) is located within the UNESCO Heritage Site of "Kalwaria Zebrzydowska: the Mannerist Architectural and Park Landscape Complex and Pilgrimage Park," which was inscribed on the UNESCO World Heritage List in 1999. A year later, this area was also announced as a monument to history. It has a buffer zone, which covers $8.5 \mathrm{~km}^{2}$ of the area of the commune. When defining its borders, the range of the viewing zone was taken into account allowing for a perception in a broader landscape context. This zone also includes the Lanckorona urban layout entered into the register of monuments, e.g. [20].

This is the reason why the principles of protection of cultural and landscape values have been included in the local spatial development plan of the commune of Lanckorona [24]. The most-important tasks are as follows:

a) cooperating with monument protection services in taking protective measures towards historic objects and complexes protected by law (or those demanded to be protected) and, in particular, creating incentives for those interested in the management and renovation of the historic buildings;

b) preserving the historical spatial structure and urban composition of the "downtown" area of Lanckorona along with the castle complex;

c) exhibiting historic monuments and historical communication routes as well as enriching the traditional service and commercial function of the market, with a particular emphasis on rendering services to tourists;

d) maintaining traditional directions of development of the basic settlement structure;

e) maintaining the hamlet structure of peripheral areas as much as possible, with reference to the historic road network as well as the land and forest layout;

f) protection of the foreground of historical monuments, objects, and their exposition by prohibiting activities limiting the field of visibility (especially relates to the Old Town complex with Castle Hill);

g) strict protection of historic buildings entered into registers and making settlements in the case of plans for objects included in the list of monuments;

h) protection of the open landscape of fields, forest complexes, and valleys of the rivers and streams;

i) protection of the open areas located within the settlement areas (invested ones) and protection of the greenery in the vicinity of historic buildings;

j) shaping contemporary development as related to the scale and significant features of traditional development;

k) protection of archaeological sites;

1) promoting the cultural values of the commune through various forms of information activities and promoting their attractiveness to sightseeing tourism.

All of this means that the maintenance and implementation of any new structures and devices must not violate the requirements set for the landscapes and cultural treasures. 
In order to preserve the original small-town and residential character, the following guidelines and restrictions regarding the newly built and modernized development were included in the local plan [23]:

a) the height of the structure calculated from the ground level along the central axis of the projection of the building to the roof ridge may not exceed $9.0 \mathrm{~m}$;

b) the roofs should be symmetrical (gable or hip ones) with a slope of $40-45^{\circ}$ with eaves extended;

c) roofing finishing materials such as ceramic tiles must be similar in color to those within the conservation area and buffer zone;

d) the wall base may be plastered or tiled with broken stone, while any use of plastic siding to finish the facade within the conservation area and in the buffer zone is prohibited;

e) it is recommended to use warm colors (from white to brown);

f) it is recommended to include wooden architectural details referring to the traditional Lanckorona architecture.

In addition, in the area of strict conservation protection (i.e., in the Lanckorona urban layout from the turn of the $14^{\text {th }}$ and $15^{\text {th }}$ centuries) along with the development and communication system within the boundaries of small-town development from the turn of the $19^{\text {th }}$ and $20^{\text {th }}$ centuries and the castle-fortification establishment, the following were introduced [25]:

a) the primacy of restoration and conservation activities regarding the obligation to secure historic buildings against destruction, damage, and devastation, and the possibility to adapt structures to contemporary functions that do not disturb the character of the complex;

b) the necessity for the State Monument Protection Service to consent to all projects related to the remodeling, renovation, reconstruction, and maintenance of the historic buildings and their surroundings as well as changes in their manner of use;

c) the obligation to maintain and protect the surrounding greenery, especially the tree stand;

d) the obligation to coordinate all projects that change the external appearance of structures located within the zone not recognized as historic with the State Monument Protection Service;

e) the obligation to coordinate all architectural and construction designs, technical infrastructure, and elements of landscape architecture, billboards, fences, etc. with the State Monument Protection Service;

f) the general obligation to preserve the historical division of plots and reduce development density (in justified cases, the State Monument Protection Service may allow for the implementation of new structures that do not interfere with the spatial order - based on designs including conservation guidelines);

g) undertaking to adapt the architectural form of style-less objects to the surrounding, or introducing "camouflage" greenery. 


\subsection{Local Spatial Development Plan for Town of Levoča (Slovakia)}

Levoča is a town located less than $30 \mathrm{~km}$ east of Poprad (Fig. 4) at an average altitude of 570 meters above mean sea level. It covers an area of $114.8 \mathrm{~km}^{2}$ and it is inhabited by nearly 15,000 people. The city is located in the valley of Levoča Stream on the southern outskirts of the Levoča hills [20]. Two km north of the city center sits Virgin Mary's Chapel on Marian Hill (Fig. 5).

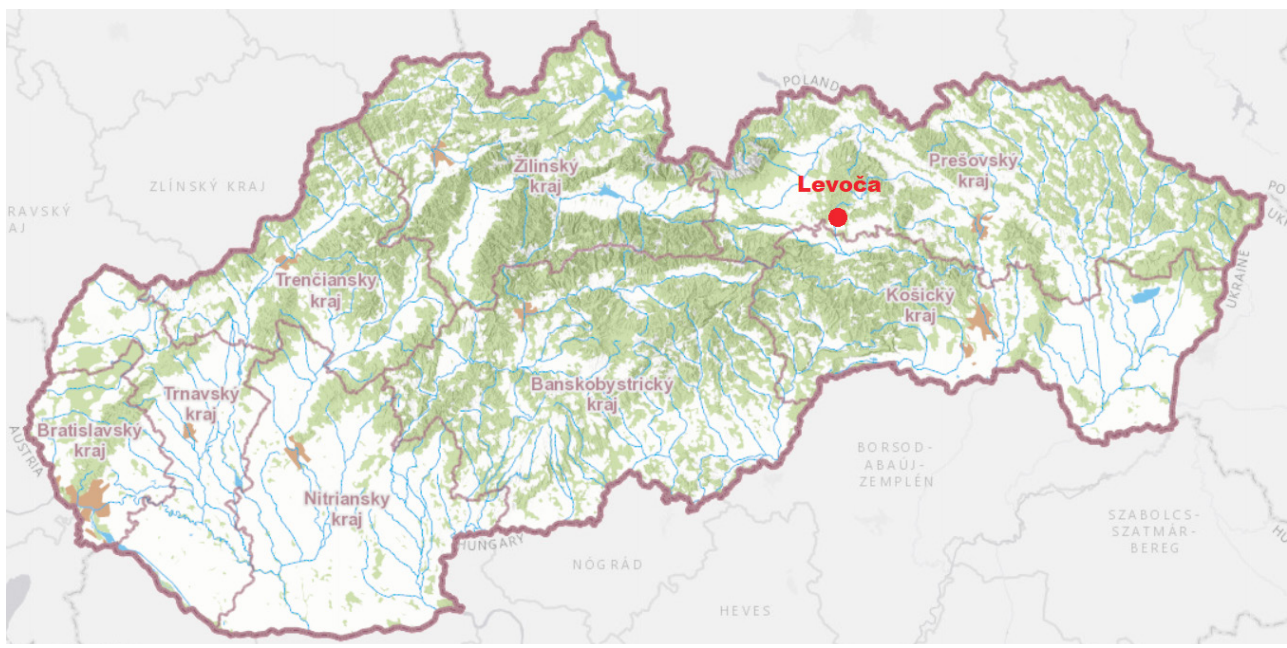

Fig. 4. Location of Levoča

Source: own study based on [7]

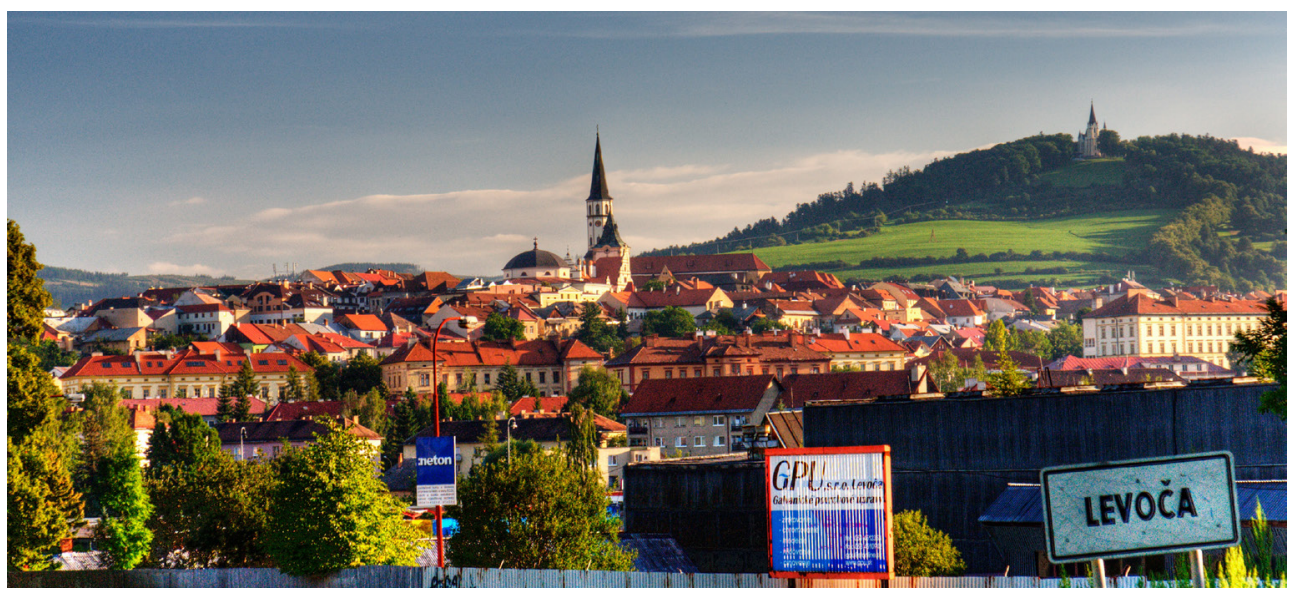

Fig. 5. Panorama of Levoča with the Marian Hill (phot. Semu)

Source: [17] 
In 2001, the urban monument reserve was established in the area enclosed by the system of medieval walls. Burgher houses prevail in this characteristic urban layout. Its central element is the rectangular market, where sacred and public buildings dominate (Fig. 6). In 2009, the monuments of Levoča were inscribed on the UNESCO World Heritage List as an extension of the entry that includes Spiš Castle, for example.

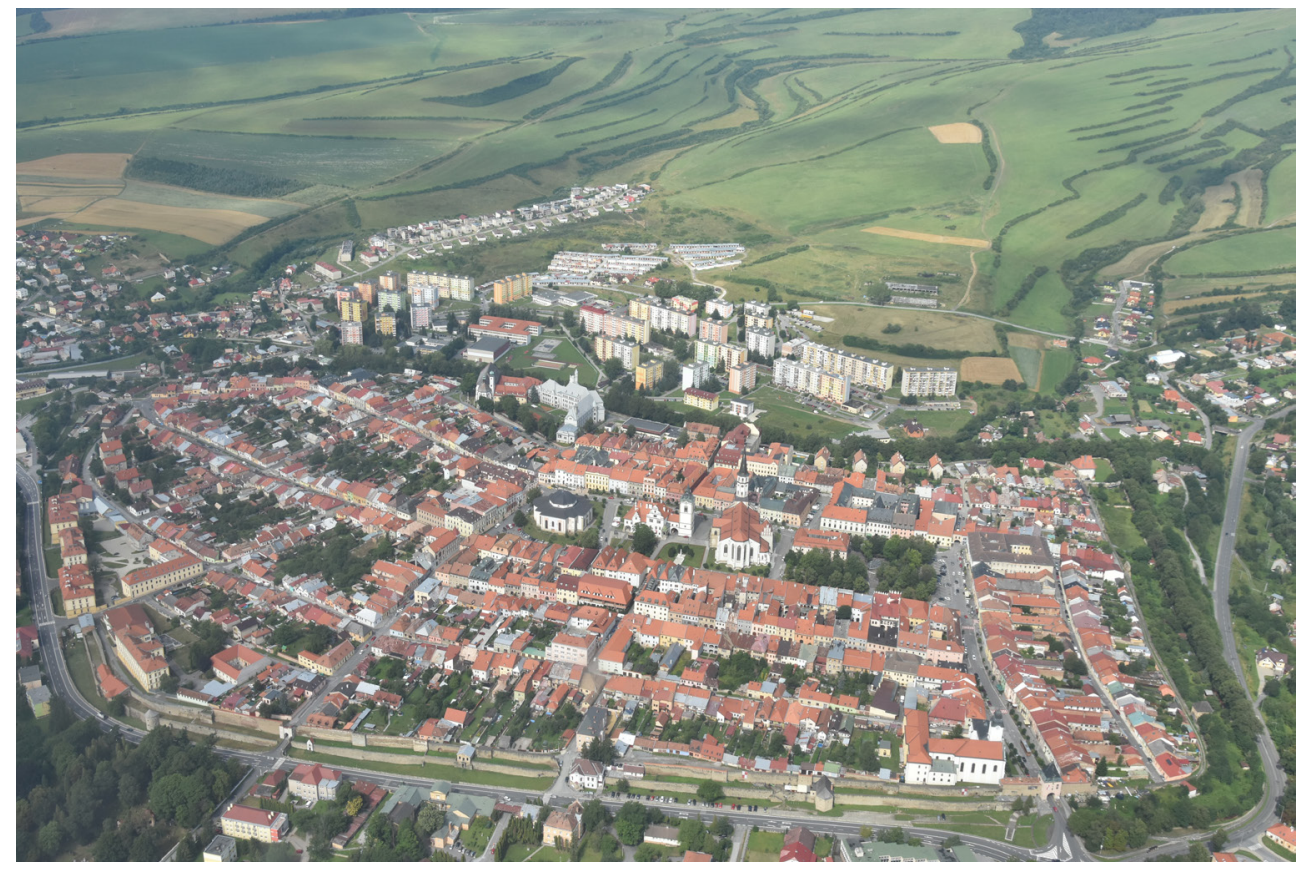

Fig. 6. Historic buildings in Levoča market square - bird's-eye view (phot. Ekkhard Issel)

Source: [10]

As noted in [2] and [19] historical objects are an integral part of the landscape. In Levoča the historical city center creates a characteristic panorama in the local landscape. It was decided not to build any tall buildings in the suburbs of Levoča so that the panorama would be preserved; and between the existing peripherally located buildings and the town center, trees should be planted to obtain visual unity. According to the local plan, the designed spatial structure cannot obstruct the following views [25]:

- of Levoča from Marian Hill and of Marian Hill from Levoča,

- from the main access roads (the existing and planned ones) to the historic center of Levoča,

- of Levoča from the tourist travel service point located on the D1 Highway (Bratislava - Kosice). 
It should be added that establishing the urban monument reserve aimed to ensure the protection and proper use of the buildings with regard to their historical, urban, architectural, landscape, and social values. Therefore, any construction work or earthworks performed on the plots or in the buildings entered into the register of monuments are possible only based on consent of the Provincial Office of the Conservator of Monuments in Prešov.

The main principles of architectural assumptions within the area of the monument reserve include the following [20]:

a) respecting the unity of the virtually unchanged urban structure while revitalizing it;

b) preserving the historical layout of the town and the layout of the plots, including preserving the backyards and wings of the tenement houses as well as the farm buildings, completing street frontage lines, and eliminating or adapting those existing buildings that have a negative visual impact on the surroundings;

c) maintaining the multifunctional character of the houses with predominantly residential function and small shops, service outlets, and craft workshops;

d) revitalization of other buildings and the construction or reconstruction of technical devices;

e) opening new service outlets that will not depend on the troublesome deliveries of goods nor require extensive warehouse spaces;

f) redirecting the architecture of the urban greenery towards its historical origins,

g) respecting the historical height-control-zones and terrain configuration.

Currently, works aimed at establishing a buffer zone for the town monument reserve are being carried out.

\section{Conclusions}

Systems of spatial planning in Poland and Slovakia are very similar. However, as far as the protection of cultural values and monuments is concerned, the following should be noted:

1. The territorial range of planning documents developed at the regional and local levels in Poland and Slovakia may vary. In general, documents prepared at the regional level in Poland relate to whole provinces, and in Slovakia - to whole regions, while at the local level - to communes. In Slovakia, however, these boundaries may be different, which could result in a better adjustment of the boundaries of the areas covered by the planning documents (as far as the protection of the areas with special historic values is concerned, especially with respect to former historical lands). 
2. In the absence of a local development plan, construction permits may be issued in both countries if the real estate to be covered by this decision meets the conditions specified in the regulations. Although there is no equivalent of the Polish planning permission in Slovakia, each potential construction permit is consulted with the Provincial Conservator of Monuments in both countries.

3. In both countries, the obligation to prepare local spatial development plans is imposed on the communes. However, the plan in Slovakia is much-less-detailed and also regards the protection of cultural values and historical monuments. Only in the zonal development plan (if one exists), can more-detailed solutions be found. Nevertheless, the only institution that has the right to determine, impose, and approve any possible changes in the historical areas of Slovakia is the Provincial Conservator of Monuments.

4. In addition to protection of the landscape, the local development plan for Lanckorona also takes guidelines and restrictions into account for newly constructed and modernized buildings. However, the plans developed in Slovakia are much-less-detailed. Therefore, the one prepared for Levoča deals only with the protection of the landscape with the town's silhouette. Thus, the provisions of the local development plan for the commune of Lanckorona provide better protection and emphasize the historic character of the village.

5. Inscribing an area on the UNESCO World Heritage List has no effect on the records of planning documents. It should be remembered, though, that UNESCO may delete such an area from the World Heritage List if a building structure that would not fit into the surroundings was to be erected in the area.

\section{References}

[1] Adamczyk T., Bieda A.: Intended Use of Real Estate as a Time Changeable Attribute for Determining Compensation for Nationalized and Expropriated Lands. Real Estate Management and Valuation, vol. 22, no. 4, 2014, pp. 35-50.

[2] Bartoš K., Pukanská K., Gajdošík J., Krajňák M.: The issue of documentation of hardly accessible historical monuments by using of photogrammetry and laser scanner techniques. Geoinformatics FCE CTU, vol. 6, 2011, pp. 40-47.

[3] Bieda A., Hanus P., Hycner R.: Geodezyjne aspekty planowania przestrzennego i wybranych opracowań projektowych. Wydawnictwo Gall, Katowice 2012.

[4] Bieda A., Parzych P.: Development of spatial politics of monumental towns based on Krakow example. International Multidisciplinary Scientific GeoConference SGEM - Surveying Geology \& Mining Ecology Management, vol. 2, 2013, pp. 143-150. 
[5] Cieślak I.: Analiza systemu planowania przestrzennego we Francji w nawiazaniu do systemu polskiego. Acta Scientiarum Polonorum. Administratio Locorum, vol. 9, nr 2, 2010, pp. 5-16.

[6] Geoportal of Poland, http://www.geoportal.gov.pl/ [access: 15.12.2017].

[7] Geoportal of Slovakia, https://www.geoportal.sk/ [access: 15.12.2017].

[8] Golej J.: Porovnanie systémov územného plánovania v Taliansku a na Slovensku. Nehnutel'nosti a bývanie, no. 1, 2012, pp. 27-37.

[9] Gross M., Źróbek R., Špirková D.: Public Real Estate Management System in the Procedural Approach - A Case Study of Poland and Slovakia. Real Estate Management and Valuation, vol. 22, no. 3, 2014, pp. 63-72.

[10] Historic buildings in Levoča market square - bird's-eye view, https:// de.wikipedia.org/w/index.php?title=Datei:068_Levoca_(Leutschau). JPG\&filetimestamp=20171121201149\& [access: 15.12.2017].

[11] Historical development of market in Lanckorona, https://pl.wikipedia.org/ wiki/Plik:Lanckorona_20050724_1330_2439.jpg [access: 15.12.2017].

[12] Koreleski K.: The system of spatial planning and land management in Poland. Geomatics and Environmental Engineering, vol. 3, no. 2, 2009, pp. 27-42.

[13] Krajewska M., Źróbek S., Kovač M.Š.: The role of spatial planning in the investment process in Poland and Slovenia. Real Estate Management and Valuation, vol. 22, no. 2, 2014, pp. 52-66.

[14] Kwartnik-Pruc A., Przewięźlikowska A.: Porównanie funkcjonowania planowania przestrzennego w Polsce iw Niemczech. Geomatics and Environmental Engineering, vol. 1, no. 3, 2007, pp. 149-160.

[15] Muczyński A., Źróbek R., Foryś I., Kempa O., Bieda A., Pęska A., Kazak J., Szewrański S., Renigier-Biłozor M., Biłozor A.: Real estate management: spatial analysis supported by GIS tools. GIS Forum, Croatian Information Technology Society, Zagreb 2015.

[16] Ogrodnik K.: Ochrona dziedzictwa kulturowego w miejscowym planie zagospodarowania przestrzennego. Architecturae et Artibus, Architecturae et Artibus, no. 2, 2013, pp. 13-24.

[17] Panorama of Levoča with the Marian Hill, https://de.wikipedia.org/wiki/ Datei:Levoca_View1.jpg [access: 15.12.2017].

[18] Pawlikowska E., Popek P., Bieda A. Moteva M., Stoeva A.: Analysis of the Legal Methods of Agricultural Land Protection in Central Europe On the Example of Poland and Bulgaria. Real Estate Management and Valuation, vol. 25, no. 2, 2017, pp. 58-71.

[19] Pukanská K.: 3D visualisation of cultural heritage by using laser scanning digital photogrammetry. VŠB-TU, Ostrava 2013.

[20] Sala B.: Porównanie systemów planowania przestrzennego w Polsce i na Stowacji. Akademia Górniczo-Hutnicza, Kraków 2016 [M.Sc. thesis, unpublished].

[21] Tölle A.: Zintegrowane formy planowania i zarzadzania rozwojem lokalnym a instrumentarium planistyczne - system polski na tle systemu niemieckiego. Studia Regionalne i Lokalne, nr 3(57), 2014, pp. 60-76. 
[22] Topczewska T.: Integrated planning of development and revitalisation of cities in selected countries of the European union and in Poland. Człowiek i Środowisko, t. 36, nr 3, 2012, pp. 21-40.

[23] Welc-Jędrzejewska J.: Ochrona zabytków w planowaniu przestrzennym. Kurier Konserwatorski, nr 1, 2008, pp. 5-8.

[24] Uchwała Nr VII/62/2003 Rady Gminy Lanckorona z dnia 15 maja 2003 roku w sprawie uchwalenia miejscowego planu zagospodarowania przestrzennego Gminy Lanckorona. Dz. Urz. Woj. Małopolskiego Nr 164, poz. 2113 z poźn. zm. [Resolution No. VII/62/2003 of the Lanckorona Commune Council of 15 May 2003 on the adoption of a local spatial development plan for the Commune of Lanckorona. Official Journal of the Malopolska province No. 164, item 2113 as amended].

[25] Ustawa z dnia 8 marca 1990 r. o samorzadzie gminnym, tekst jednolity z dnia 15 września 2017 r. Dz.U. 2017, poz. 1875 z późn. zm. [Act of 8 March 1990 on commune self-government, consolidated text of 15 September 2017. Journal of Laws of 2017, item 1875 as amended].

[26] Ustawa z dnia 27 marca 2003 r. o planowaniu i zagospodarowaniu przestrzennym, tekst jednolity z dnia 11 maja 2017 r. Dz.U. 2017, poz. 1073 [Act of 27 March 2003 on spatial planning and land development, consolidated text of 11 May 2017. Journal of Laws of 2017, item 1073].

[27] Územný plán mesta Levoča - Uznesenie Mestského Zastupitel’stva číslo 14/C/1 zo dňa 26. augusta 2004 [Local spatial development plan for the town of Levoča - resolution of the Town Council No. 14/C/1 of 26 August 2004].

[28] View of Lanckorona Mountain, https://pl.wikipedia.org/wiki/Plik:Lanckorona_BMa3.jpg [access: 15.12.2017].

[29] Zákon Slovenskej Národnej Rady zo dňa 27. apríla 1976 č. 50/1976 Zb. o územnom plánovaní a stavebnom poriadku (stavebný zákon) [Act of the Slovak National Council of 27 April 1976 No. 50/1976 on spatial planning and building regulations (construction law)].

[30] Zákon Slovenskej Národnej Rady zo dňa 6. septembra 1990 č. 369/1990 Zb. o obecnom zriadení [Act of the Slovak National Council of 6 September 1990 No. 369/1990 on local self-government].

\section{Planowanie przestrzenne w miejscowościach o szczególnych walorach zabytkowych na przykładzie Polski i Słowacji}

Streszczenie: Jednym z celów planowania przestrzennego jest ochrona dziedzictwa kulturowego i zabytków. Konieczność uwzględnienia go w opracowaniach planistycznych powoduje, że $\mathrm{w}$ procedury planowania przestrzennego włączane są działania związane ze świadomym kształtowaniem krajobrazów 
kulturowych oraz opieką nad obiektami historycznymi. Mimo to uważa się, że w tworzonych w Polsce dokumentach planistycznych możliwości te są wykorzystywane niedostatecznie.

Celem artykułu jest porównanie systemów planowania przestrzennego w Polsce i na Słowacji ze szczególnym uwzględnieniem uwarunkowań, jakie muszą zostać wzięte pod uwagę przy tworzeniu dokumentów planistycznych w miejscowościach z architekturą zabytkową.

Analiza przykładowej dokumentacji stworzonej dla miast o walorach historycznych (Lanckorony w Polsce oraz Lewoczy na Słowacji) pozwoliła autorom na stwierdzenie, że miejscowe plany zagospodarowania przestrzennego na Słowacji zawierają mniej szczegółów związanych z ochroną wartości kulturowych i zabytków niż plany uchwalane w Polsce. Jest tak, ponieważ jedyną instytucja, która posiada w tym zakresie na Słowacji kompetencje, jest wojewódzki konserwator zabytków.

\section{Słowa}

kluczowe: Lanckorona, Lewocza, miejscowy plan zagospodarowania przestrzennego, ochrona wartości kulturowych, ochrona zabytków, UNESCO 